\title{
PENILAIAN PROSES BERORIENTASI KKNI DI JURUSAN PENDIDIKAN TEKNIK INFORMATIKA, UNDIKSHA
}

\author{
P. Wayan Arta Suyasa ${ }^{1}$,Dewa Gede Hendra Divayana ${ }^{2}$ \\ Pendidikan Teknik Informatika,Universitas Pendidikan Ganesha \\ Singaraja,Indonesia
}

e-mail: arta.suyasa@undiksha.ac.id, hendra.divayana@undiksha.ac.id ${ }^{2}$

\begin{abstract}
Abstrak
Penyelenggaraan pendidikan yang bermutu tinggi harus didukung oleh proses pembelajaran yang bermutu tinggi, serta kurikulum yang relevan dengan kebutuhan masyarakat saat ini, seperti penyelenggaraan kurikulum berbasis Kerangka Kualifikasi Nasional Indonesia (KKNI). Penilaian setiap mata kuliah terkait dengan implementasi kurikulum berbasis $\mathrm{KKNI}$ terdiri dari penilaian proses perkuliahan (yang meliputi sikap, partisipasi dalam perkuliahan, penyelesaian tugas-tugas dengan bobot $60 \%$ ) dan penilaian produk (yang meliputi UTS dan UAS dengan bobot $40 \%$ ). Penelitian ini bertujuan untuk membuat instrumen penilaian proses yang standar, sehingga bisa digunakan sebagai acuan dalam pelaksanaan penilaian proses perkuliahan baik di kelas maupun luar kelas. Penelitian ini merupakan penelitian pengembangan dalam kegiatan pembakuan instrumen berbentuk rubrik penilaian proses. Terdapat beberapa langkah yang dilakukan dalam pengembangan instrumen penilaian proses, yaitu: 1) membuat kajian teoritik untuk merumuskan aspek-aspek atau indikator dari instrumen yang akan dikembangkan, 2) menyusun kisi-kisi instrumen, 3) menyusun butir-butir instrumen, 4) melakukan validasi instrumen secara teoritik, dan 5 ) merakit butir-butir instrumen menjadi instrumen final. Hasil uji validitas yang dilakukan oleh pakar yang dianalisis menggunakan formula Gregory adalah 0.83 . Nilai ini berada dalam kategori sangat tinggi.
\end{abstract}

Katakunci: penilaian, proses, KKNI

\begin{abstract}
The implementation of the high quality of education must be supported by the high quality of learning process, and the relevant curriculum with the society needs nowadays, such as the implication of curriculum base KKNI. Assessment in every subject learning related with the implementation of curriculum base KKNI consisted of learning process assessment (included attitude, class participation, doing assigments with value 60\%) and product assessment (incuded UTS and UAS with value 40\%). This research was aimed to make an the standard assessment process instrument, so it could be used as a reference in doing process assessment learning either in class or out of class. This research was the development research in the instrument standardization activity in form of process assessment rubric. There were some ways done in the development of process assessment instrument, namely: 1) making theoritic investigation to formulate aspects or indicators from the developed instrument, 2) arranging the instrument designs, 3) arranging the instument questions, 4) doing the instrument validation theoritically, and 5) assembling the instrument questions to be the final instrument. The result of validity test which was done by judges analyzed by using Gregory formula is 0.83 . This value is in very high category.
\end{abstract}

Keywords: assessment, process, KKNI 


\section{PENDAHULUAN}

Dalam perspektif KKNI, setiap program studi diharuskan memperjelas "profil lulusan" yang didapatkan melalui kegiatan pelacakan studi, studi kelayakan dan analisis kebutuhan di masyarakat. Profil lulusan mencerminkan kemampuan minimal yang harus dikuasai mahasiswa setelah lulus yang merujuk pada empat aspek kebutuhan, yakni: (1) sikap (attitude), (2) bidang kemampuan kerja, (3) pengetahuan, serta (4) manajerial dan tanggung jawab. Keempat kemampuan tersebut kemudian harus dijabarkan ke dalam sebuah capaian pembelajaran (learning outcome) pada setiap mata kuliah di program studi. Sehingga nantinya, semua perencanaan pembelajaran atau Rencana Pelaksanaan Semester (RPS) harus didasarkan pada capaian pembelajaran (Learning Outcome) yang sesuai dengan kebutuhan profil lulusan.

Berdasarkan pedoman pengembangan kurikulum Undiksha 2016 dan buku pedoman studi tahun 2016, penilaian setiap mata kuliah terkait dengan implementasi kurikulum Undiksha 2016 (KKNI) terdiri dari penilaian proses perkuliahan (yang meliputi sikap, partisipasi dalam perkuliahan, penyelesaian tugastugas dengan bobot $60 \%$ ) dan penilaian produk (yang meliputi UTS dan UAS dengan bobot $40 \%$ ). Penilaian proses dan produk tersebut berkaitan dengan prinsip penilaian, teknik dan instrumen penilaian, mekanisme dan prosedur penilaian, pelaksanaan penilaian, pelaporan penilaian, dan kelulusan mahasiswa. Prinsip penilaian menyangkut kebermanfaatan secara hakiki suatu proses penilaian. Maka dari itu, prinsip penilaian mencakup prinsip edukatif, otentik, objektif, akuntabel, dan transparan yang dilakukan secara terintegrasi. Prinsip edukatif dimaksudkan bahwa suatu penilaian dapat memotivasi mahasiswanya agar mampu memperbaiki perencanaan dan cara belajarnya sehingga dapat meraih capaian pembelajaran lulusan. Sedangkan prinsip otentik merupakan penilaian yang berorientasi pada proses belajar yang nyata dan berkesinambungan serta hasil belajar yang mencerminkan kemampuan mahasiswa pada saat proses pembelajaran berlangsung. Prinsip objektif merupakan prinsip penilaian yang didasarkan pada standar yang disepakati antara dosen dan mahasiswa, dalam hal ini dosen tidak subjektif dalam melakukan penilaian terhadap mahasiswa. Prinsip akuntabel merupakan prinsip penilaian dimana hasil penilaian bisa dipertanggungjawabkan. Penilaian harus dilaksanakan sesuai dengan prosedur dan kriteria yang jelas, disepakati pada awal perkuliahan, dan dipahami oleh mahasiswa. Sedangkan prinsip transparan merupakan prinsip penilaian yang prosedur dan hasil penilaiannya dapat diakses oleh semua pemangku kepentingan.

Dalam implementasinya di lapangan, masih banyak ditemukan evaluator (dosen) yang belum mampu melakukan penilaian seperti apa yang tertuang dalam prinsipprinsip penilaian. Kondisi ini terjadi pada program studi Pendidikan Teknik Informatika (PTI). PTI merupakan salah satu prodi yang ada di Fakultas Teknik dan Kejuruan, Undiksha. Sebagian besar dosen di PTI masih kesulitan dalam melakukan proses penilaian, utamanya saat melakukan penilaian proses. Mereka umumnya kebingungan dalam mendefinisikan indikator-indikator apa saja yang harus dimasukkan dalam penilaian proses, baik yang mencakup aspek penilaian sikap, partisipasi dalam perkuliahan, maupun penyelesaian tugas-tugas. Selain itu belum adanya instumen penilaian yang baku, mengakibatkan setiap dosen memiliki asumsi sendiri-sendiri dalam melakukan proses penilaian. Akibatnya, kecenderungan hasil penilaian yang bersifat subyektif, kurang otentik, dan tidak akuntabel tidak bisa dihindarkan.

Berkaca dari kondisi tersebut, peneliti mencoba memberikan solusi berupa pengembangan penilaian proses dalam implementasi kurikulum KKNI di program studi Pendidikan Teknik Informatika, Undiksha. Melalui pengembangan instrumen penilaian proses tersebut diharapkan dapat digunakan sebagai acuan atau pedoman, khususnya bagi para dosen di prodi $\mathrm{PTI}$ saat melakukan penilaian 
proses perkuliahan baik di kelas maupun luar kelas, sehingga tidak lagi ditemukan hasil penilaian yang bersifat subyektif, kurang otentik, maupun tidak akuntabel.

Penilaian merupakan bagian yang tidak dapat dipisahkan dalam suatu proses belajar-mengajar ${ }^{[1]}$. Penilaian merupakan serangkaian kegiatan untuk memperoleh, menganalisis, dan menafsirkan proses dan hasil belajar siswa yang dilakukan secara sistematis, dan berkesinambungan untuk memperoleh informasi yang bermakna mengenai ketercapaian kompetensi dasar siswa berdasarkan indikator yang telah ditetapkan sebelumnya ${ }^{[2]}$. Penilaian dilakukan secara menyeluruh baik ranah pengetahuan, sikap, dan keterampilan. Dalam penilaian, pendidik mengumpulkan berbagai informasi yang dapat diolah, dianalisis, dan diinterpretasi untuk mengetahui hal-hal berikut 1) kemajuan yang dialami peserta didik dalam proses pencapaian kompetensi dasar yang telah ditetapkan dalam rencana pembelajaran secara mendidik, 2) kemajuan yang dialami peserta didik dalam memahami dirinya dalam rangka pengembangan kepribadiannya dan dalam rangka pengambilan keputusan seperti pemanfaatan waktu luang, atau pemilihan program kegiatan di luar jam sekolah, atau cita-cita kelanjutan studinya kelak, 3) hambatan atau kesulitan yang dialami peserta didik dalam mengikuti proses pembelajaran, sehingga dapat dirancang proses pembelajaran remedial (perbaikan) atau proses pembelajaran pengayaan (peningkatan, penguatan, atau pemantapan), dan 4) kelemahan dan kekurangan proses pembelajaran yang sedang berlangsung, sehingga dalam proses pembelajaran berikutnya akan dapat diantisipasi kelemahan dan kekurangan tersebut ${ }^{[3]}$.

Dalam melaksanakan penilaian pembelajaran yang mendidik, pendidik sebaiknya memperhatikan hal-hal yaitu 1) pendidik memandang penilaian dan kegiatan belajar-mengajar secara terpadu, 2) pendidik mengembangkan strategi yang mendorong dan memperkuat penilaian sebagai cermin diri, 3) pendidik melakukan berbagai strategi penilaian di dalam program pembelajaran untuk menyediakan berbagai jenis informasi tentang hasil belajar peserta didik, 4) pendidik mempertimbangkan berbagai kebutuhan khusus peserta didik, 5) pendidik mengembangkan dan menyediakan sistem pencatatan yang bervariasi dalam pengamatan kegiatan belajar peserta didik, 6) Pendidik menggunakan cara dan alat penilaian yang bervariasi, misalnya dengan cara gabungan dua atau lebih bentuk penilaian unjuk kerja, penilaian sikap, penilaian tertulis, penilaian proyek, penilaian produk, penggunaan portofolio, dan penilaian diri yang mencakup domain kognitif, psikomotor, dan afektif, serta 7) pendidik mendidik peserta didik dan meningkatkan mutu proses pembelajaran seefektif mungkin ${ }^{[4]}$.

Standar pelaksanaan penilaian proses diawali dengan membuat suatu perencanaan penilaian yang meliputi menyusun, menyampaikan, menyepakati tahap, teknik, instrumen, kriteria, indikator, dan bobot penilaian antara penilai dan yang dinilai (peserta didik) sesuai dengan rencana pembelajaran. Teknik penilaian proses dalam pembelajaran dapat dilakukan dengan teknik observasi, partisipasi, unjuk kerja, tes tertulis, tes lisan, dan angket. Instrumen penilaian proses pembelajaran dapat dilakukan dengan rubrik dan/atau penilaian hasil pembelajaran dapat dilakukan dalam bentuk portofolio atau karya desain. Sedangkan, penilaian sikap dapat menggunakan teknik penilaian observasi. Penilaian terhadap penguasaan pengetahuan, keterampilan umum, dan keterampilan khusus dilakukan dengan memilih satu atau kombinasi dari berbagai teknik dan instrumen penilaian (seperti misalnya observasi, partisipasi, unjuk kerja, tes tertulis, tes lisan, dan angket). Setelah perencanaan penilaian selesai dilakukan, selanjutnya pendidik melaksanakan proses penilaian berdasarkan apa yang sudah disepakati dan dibuat pada tahap perencanaan. Penilaian dapat dilakukan pada saat pembelajaran atau setelah pembelajaran berlangsung, dengan 
memberikan beberapa soal atau tugas kepada peserta didik. Sejalan dengan itu, pendidik dapat melakukan observasi terkait dengan kinerja peserta didik dalam mengerjakan tugas yang diberikan, kemudian memberikan umpan balik ataupun konfirmasi terkait dengan hasil kinerja mereka, untuk selanjutnya bisa ditentukan/diputuskan nilai akhir sebagai hasil belajar dari peserta didik.

Pendidik dalam melaksanakan suatu proses penilaian, baik itu menyangkut pelaksanaan penilaian proses maupun produk hendaknya dilakukan dengan mengikuti prinsip-prinsip penilaian yakni edukatif, otentik, objektif, akuntabel, dan transparan yang dilakukan secara terintegrasi ${ }^{[5]}$.

Merujuk pada panduan pelaksanaan penilaian proses dan hasil belajar implementasi kurikulum Undiksha 2016, prodi Pendidikan Teknik Informatika (PTI), menyusun suatu standar penilaian proses dengan mengikuti prinsip-prinsip penilaian yakni edukatif, otentik, objektif, akuntabel, dan transparan yang dilakukan secara terintegrasi. Prinsip edukatif dimaksudkan bahwa suatu penilaian dapat memotivasi mahasiswanya agar mampu memperbaiki perencanaan dan cara belajarnya sehingga dapat meraih capaian pembelajaran lulusan. Sedangkan prinsip otentik merupakan penilaian yang berorientasi pada proses belajar yang nyata dan berkesinambungan serta hasil belajar yang mencerminkan kemampuan mahasiswa pada saat proses pembelajaran berlangsung. Prinsip objektif merupakan prinsip penilaian yang didasarkan pada standar yang disepakati antara dosen dan mahasiswa, dalam hal ini dosen tidak subjektif dalam melakukan penilaian terhadap mahasiswa. Prinsip akuntabel merupakan prinsip penilaian dimana hasil penilaian bisa dipertanggungjawabkan. Penilaian harus dilaksanakan sesuai dengan prosedur dan kriteria yang jelas, disepakati pada awal perkuliahan, dan dipahami oleh mahasiswa. Sedangkan prinsip transparan merupakan prinsip penilaian yang prosedur dan hasil penilaiannya dapat diakses oleh semua pemangku kepentingan. Berikut adalah standar pelaksanaan penilaian proses di prodi PTI. 


\begin{tabular}{|c|c|c|}
\hline \multicolumn{2}{|l|}{ PERENCANAAN PENILAIAN } & \multirow{2}{*}{$\begin{array}{l}\text { Pelaksana Penilai } \\
\text { Dosen atau Tim Dosen } \\
\text { pengampu tanpa atau dengan } \\
\text { menyertakan pihak lain. }\end{array}$} \\
\hline \multirow[t]{2}{*}{$\begin{array}{l}\text { Analisis Kurikulum } \\
\text { untuk mementukan SK, } \\
\text { KD, Indikator }\end{array}$} & \multirow{2}{*}{$\begin{array}{l}\text { Menentukan teknik } \\
\text { penilaian, menyusun } \\
\text { instrumen, kriteria, dan } \\
\text { bobot penilaian }\end{array}$} & \\
\hline & & \multirow{2}{*}{$\begin{array}{l}\text { Teknik Penilai } \\
\text { Observasi, partisipasi, unjuk } \\
\text { kerja, tes tertulis, tes lisan, dan } \\
\text { angket. }\end{array}$} \\
\hline \multicolumn{2}{|l|}{ PELAKSANAAN PENILAIAN } & \\
\hline & $\begin{array}{l}\text { Memberikan tugas } \\
\text { atau soal }\end{array}$ & \multirow{5}{*}{$\begin{array}{l}\text { Indikator dan Bobot Penilaian } \\
\text { Penilaian Proses (bobot 60\%) } \\
\text { 1. Sikap dan Partisipasi dalam } \\
\text { pembelajaran (bobot 20\%) } \\
\text { 2. Penyelesaian tugas-tugas } \\
\text { (bobot } 40 \% \text { ) } \\
\text { Penilain Produk (bobot } 40 \% \text { ) } \\
\text { 1. UTS (bobot } 15 \% \text { ) } \\
\text { 2. UAS (bobot } 25 \% \text { ) }\end{array}$} \\
\hline & $\nabla$ & \\
\hline & $\begin{array}{l}\text { Observasi kinerja } \\
\text { peserta didik }\end{array}$ & \\
\hline & $\nabla$ & \\
\hline & $\begin{array}{l}\text { Pemberian nilai akhir } \\
\text { pada peserta didik }\end{array}$ & \\
\hline
\end{tabular}

Kategori Nilai
\begin{tabular}{|r|c|c|}
\hline SP & NA & NH \\
\hline $96-100$ & 4.00 & A \\
\hline $91-95$ & 3.75 & A- \\
\hline $86-90$ & 3.25 & B+ \\
\hline $81-85$ & 3.00 & B \\
\hline $76-80$ & 2.75 & B- \\
\hline $65-75$ & 2.00 & C \\
\hline $40-64$ & 1.00 & D \\
\hline $0-39$ & 0.00 & E \\
\hline
\end{tabular}

Ket: SP : Skor Persentil, NA : Nilai Angka, NH : Nilai Huruf

\begin{tabular}{|} 
Format Penilaian \\
\begin{tabular}{|c|c|c|c|c|c|c|}
\hline \multirow{2}{*}{ No. } & \multirow{2}{*}{ NIM } & $\begin{array}{c}\text { Nama } \\
\text { Mahasiswa }\end{array}$ & \multicolumn{2}{|c|}{$\begin{array}{c}\text { Penilaian } \\
\text { Proses }\end{array}$} & \multicolumn{2}{c|}{$\begin{array}{c}\text { Penilaian } \\
\text { Produk }\end{array}$} \\
\cline { 4 - 7 } & & $\begin{array}{l}\text { Sikap dan } \\
\text { Partisipasi }\end{array}$ & Tugas & UTS & UAS \\
\hline & & & & & & \\
\hline & & & & & & \\
\hline & & & & & & \\
\hline & & & & & & \\
\hline & & & & & & \\
\hline & & & & & & \\
\hline & & & & & & \\
\hline
\end{tabular}
\end{tabular}

Gambar 1. Standar Pelaksanaan Penilaian Proses di Prodi PTI (Diadaptasi dari Panduan

Pelaksanaan Penilaian Proses dan Hasil Belajar Implementasi Kurikulum Undiksha, 2016)

\section{METODE}

Penelitian ini merupakan penelitian pengembangan dalam kegiatan pembakuan instrumen. Instrumen yang dikembangkan adalah instrumen penilaian proses dalam bentuk rubrik. Terdapat beberapa langkah yang dilakukan dalam pengembangan instrumen penilaian proses, yaitu: 1) membuat kajian teoritik untuk merumuskan aspek-aspek atau indikator dari instrumen yang akan dikembangkan, 2) menyusun kisi-kisi instrumen, 3) menyusun butir-butir instrumen, 4) melakukan validasi instrumen secara teoritik, dan 5) merakit butir-butir instrumen menjadi instrumen final ${ }^{[6]}$.

Pada penelitian ini, data yang akan dikumpulkan adalah data kualitatif dan data kuantitatif. Data kualitatif dan data kuantitatif ini bersumber dari validasi pakar. Untuk memperoleh kedua jenis data tersebut, maka dalam penelitian ini digunakan instrumen dalam bentuk kuesioner. Dalam penelitian ini, instrumen yang akan digunakan untuk menjaring data berupa instrumen penilaian proses. Instrumen ini dikembangkan berdasarkan 
dua (2) aspek yakni aspek sikap dan partisipasi dalam perkuliahan serta aspek pengerjaan tugas-tugas

Sikap merupakan perilaku benar dan berbudaya sebagai hasil dari internalisasi dan aktualisasi nilai dan norma yang tercermin dalam kehidupan spiritual dan sosial melalui proses pembelajaran, pengalaman kerja mahasiswa, penelitian dan/atau pengabdian kepada masyarakat yang terkait pembelajaran (Panduan Pelaksanaan Penilaian Proses dan Hasil Belajar Implementasi Kurikulum Undiksha, 2016). Dalam definisi tersebut telah termasuk partisipasi dalam perkuliahan, sehingga bila dideskripsikan ke definisi operasional bahwa sikap dan partisipasi merupakan suatu predisposisi dan disposisi (perilaku) terhadap suatu kegiatan akademik (perkuliahan, diskusi kelas dalam perkuliahan, workshop dan kerja kelompok). Dalam penelitian ini, yang dimaksud dengan sikap dan partisipasi dalam perkuliahan, yakni suatu perilaku terhadap suatu kegiatan akademik (perkuliahan, diskusi kelas dalam perkuliahan, workshop dan kerja kelompok), dengan menekankan pada aspek kedisiplinan, penampilan, kesantunan, kemampuan bekerjasama, kemampuan berkomunikasi, komitmen, keteladanan, semangat, empati, serta tanggungjawab.

Tugas-tugas dalam perkuliahan yang dimaksud adalah penyelesaian tugas yang diberikan oleh dosen dalam perkuliahan untuk mencapai capaian pembelajaran yang dirancang. Dalam penelitian ini, penilaian terhadap tugas-tugas perkuliahan dilakukan melalui penilaian kinerja yang diselenggarakan melalui praktikum, praktik, presentasi, simulasi, diskusi, praktik lapangan, penulisan buah pikiran (makalah).

Data penelitian yang digunakan berupa data kualitatif dan data kuantitatif. Data-data tersebut kemudian diolah menggunakan analisis data, salah satunya adalah formula Gregory untuk menguji validitas isi dari instrumen yang dikembangkan. Prosedur untuk menentukan koefisien validitas isi didasarkan pada hasil penilaian para pakar, untuk selanjutnya dimasukkan ke dalam tabulasi silang $2 \times 2^{[7]}$.

\section{HASIL DAN PEMBAHASAN}

Dalam penelitian ini, instrumen yang dikembangkan adalah instrumen penilaian proses, dalam bentuk rubrik. Instrumen ini dikembangkan berdasarkan dua (2) aspek yakni aspek sikap dan partisipasi dalam perkuliahan serta aspek pengerjaan tugastugas. Berikut adalah langkah-langkah yang dilakukan dalam pengembangan instrumen penilaian proses.

\section{Membuat kajian teoritik untuk merumuskan aspek-aspek atau indikator dari instrumen yang akan dikembangkan}

Dalam kegiatan pengembangan instrumen, sebelum menyusun butir-butir instrumen, langkah yang harus dilakukan adalah melakukan kajian teoritik untuk merumuskan aspek-aspek atau indikator yang hendak dibuat. Dalam penelitian ini, instrumen yang dikembangkan berupa instrumen penilaian proses dalam bentuk rubrik, dengan mengacu pada dua (2) aspek yakni aspek sikap dan partisipasi dalam perkuliahan serta aspek pengerjaan tugas-tugas. Adapun definisi konsep dari masing-masing aspek tersebut yakni sebagai berikut.

\section{a. Aspek Sikap dan Partisipasi dalam Perkuliahan}

Sikap merupakan perilaku benar dan berbudaya sebagai hasil dari internalisasi dan aktualisasi nilai dan norma yang tercermin dalam kehidupan spiritual dan sosial melalui proses pembelajaran, pengalaman kerja mahasiswa, penelitian dan/atau pengabdian kepada masyarakat yang terkait pembelajaran (Panduan Pelaksanaan Penilaian Proses dan Hasil Belajar Implementasi Kurikulum Undiksha, 2016). Dalam definisi tersebut telah termasuk partisipasi dalam perkuliahan, sehingga bila dideskripsikan ke definisi operasional bahwa sikap dan partisipasi merupakan suatu predisposisi dan disposisi (perilaku) terhadap suatu kegiatan 
akademik (perkuliahan, diskusi kelas dalam perkuliahan, workshop dan kerja kelompok). Dalam penelitian ini, yang dimaksud dengan sikap dan partisipasi dalam perkuliahan, yakni suatu perilaku terhadap suatu kegiatan akademik (perkuliahan, diskusi kelas dalam perkuliahan, workshop dan kerja kelompok), dengan menekankan pada aspek kedisiplinan, penampilan, kesantunan, kemampuan bekerjasama, kemampuan berkomunikasi, komitmen, keteladanan, semangat, empati, serta tanggungjawab.

\section{1) Kedisiplinan}

Kedisiplinan adalah suatu kondisi yang tercipta dan terbentuk melalui proses dari serangkaian perilaku yang menunjukkan nilai-nilai ketaatan, kepatuhan, kesetiaan, keteraturan, dan atau ketertiban. Dalam penelitian ini, yang dimaksud dengan disiplin dalam perkuliahan adalah tindakan yang menunjukkan perilaku tertib dan patuh pada berbagai ketentuan dan peraturan karena didorong oleh adanya kesadaran yang ada pada dirinya, yang ditunjukkan dengan sikap: masuk ruangan/kelas tepat waktu, mengumpulkan tugas tepat waktu, memakai seragam/pakaian sesuai tata tertib, tertib dalam mengikuti perkuliahan/pembelajaran, serta membawa buku tulis/teks sesuai mata kuliah.

\section{2) Penampilan}

Penampilan adalah bentuk citra diri yang terpancar dari diri seseorang, dan juga merupakan sarana komunikasi antara seorang individu dengan individu lainnya. Dalam penelitian ini yang dimaksud dengan penampilan dalam perkuliahan adalah bentuk citra diri yang terpancar dari diri seseorang, dengan proporsi dari setiap bagiannya terstruktur secara harmonis, yang ditunjukkan dengan kebersihan dan kerapian diri, kesesuaian tata rambut, tata rias, serta tata busana.

\section{3) Kesantunan}

Kesantunan merupakan kebiasaankebiasaan menyangkut perilaku yang berlaku dalam masyarakat yang diekspresikan dengan cara yang baik atau beretika. Kesantunan merupakan fenomena kultural, sehingga apa yang dianggap santun oleh suatu kultur mungkin tidak demikian halnya dengan kultur yang lain. Dalam penelitian ini, yang dimaksud dengan kesantunan dalam perkuliahan adalah sifat yang halus dan baik dari sudut pandang tata bahasa ataupun cara berperilaku terhadap orang lain, yang ditunjukkan dengan sikap: a) hormat terhadap orang yang lebih tua, b) tidak berkata-kata kotor, kasar, dan takabur, c) tidak menyela pembicaraan diwaktu yang tidak tepat, d) meminta ijin ketika akan memasuki/keluar ruangan, serta e) mengacungkan tangan saat akan mengajukan pendapat/pertanyaan.

4) Kemampuan Bekerjasama

Bekerjasama adalah sikap mau
bekerja sama dengan kelompok,
kemampuan bekerjasama adalah suatu usaha bersama antara orang perorangan atau kelompok untuk mencapai tujuan tertentu. Dalam penelitian ini, yang dimaksud dengan sikap kemampuan bekerjasama adalah kegiatan yang dilakukan secara bersama-sama oleh lebih dari satu orang guna mewujudkan tujuan bersama, melalui cerminan sikap: a) kesediaan melakukan tugas sesuai kesepakatan, b) kesediaan membantu orang lain tanpa mengharap imbalan, c) aktif dalam kerja kelompok, d) memusatkan perhatian pada tujuan kelompok, dan e) tidak mendahulukan kepentingan pribadi

\section{5) Kemampuan Berkomunikasi}

Kemampuan berkomunikasi merupakan suatu proses penyampaian pesan dalam bentuk simbol atau lambang yang melibatkan dwiperson atau lebih yang terdiri atas pengirim (komunikator) dan penerima (komunikan) dengan maksud untuk mencapai tujuan bersama mengenai masalah atau persoalan masing-masing pihak. Kemampuan berkomunikasi adalah suatu proses penyampaian pesan dari komunikator (sender) kepada komunikan (receiver) melalui media tertentu dan menyebabkan respon. Dalam penelitian ini, yang dimaksud dengan kemampuan berkomunikasi dalam perkuliahan adalah kemampuan yang dimiliki peserta didik 
dalam melakukan suatu proses hubungan dua arah atau interaksi secara verbal, yang ditunjukkan dengan sikap a) tegas dan lugas dalam berbicara, b) dalam berbicara selalu mengacu pada data dan fakta, c) setiap respons yang ditunjukkan ke lawan bicara selalu detail dan mendalam, serta d) mampu menempatkan diri dengan lawan bicara.

\section{6) Komitmen}

Komitmen adalah penerimaan yang kuat dari individu terhadap tujuan dan nilainilai organisasi, dan individu berupaya serta berkarya dan memiliki hasrat yang kuat untuk tetap bertahan di organisasi tersebut. Menurut Kamus Besar Bahasa Indonesia (KBBI), komitmen adalah kemampuan dan kemauan untuk menyelaraskan perilaku pribadi dengan kebutuhan, prioritas dan tujuan organisasi. Dalam penelitian ini yang dimaksud dengan komitmen adalah suatu janji yang diucapkan seseorang kepada dirinya sendiri dan orang lain, yang dicerminkan dari setiap tindakan atau pun perilaku yang dijalankannya, dalam bentuk: a) berangkat dan sampai kampus tepat waktu, b) disiplin dalam belajar dan tidak kenal putus asa, c) memiliki rasa pengendalian diri seperti sabar ketika mengerjakan tugas banyak, dan d) mengikuti perkuliahan dengan tekun.

\section{7) Keteladanan}

Keteladanan merupakan upaya atau cara yang dilaksanakan oleh pemimpin agar pegawai mau meniru segala perbuatan yang dilakukannya sebagai sarana terjadinya saling mempengaruhi antar sesama manusia, utamanya guru mempengaruhi siswa. Dalam penelitian ini, yang dimaksud dengan sikap keteladanan dalam perkuliahan adalah tindakan atau setiap sesuatu yang dapat ditiru atau diikuti oleh seseorang dari orang lain yang melakukan atau mewujudkannya, yang diwujudkan dalam bentuk sikap: a) berkata sopan santun, b) berprilaku disiplin, c) berprilaku jujur, d) menjaga kebersihan kelas/ruang kuliah, dan e) melaksanakan tata tertib.

\section{8) Semangat}

Kata semangat mengandung makna bekerja secara lebih giat sehingga pekerjaan dapat diharapkan lebih cepat dan lebih baik. Semangat diartikan sebagai kecenderungan anggota organisasi berusaha lebih keras mencapai tujuan dan sasaran organisasi termasuk perasaan terikat. Dalam penelitian ini, yang dimaksud dengan sikap semangat dalam perkuliahan adalah sikap kesediaan perasaan yang memungkinkan peserta didik untuk menghasilkan usaha/kerja yang lebih banyak dan lebih baik dari sebelumnya, dan tercermin dalam bentuk sikap: a) selalu merasa kurang dengan ilmu yang sudah di dapat, b) memperhatikan dosen/teman yang sedang memaparkan/berbagi ilmu, c) memiliki dan mengembangkan sikap terbuka pada semua pengetahuan, serta d) belajar terus menerus.

9) Empati

Empati merupakan suatu aktivitas untuk memahami apa yang sedang dipikirkan dan dirasakan orang lain, serta apa yang dipikirkan dan dirasakan oleh orang yang bersangkutan (observer, perceiver) terhadap kondisi yang sedang dialami orang lain, tanpa yang bersangkutan kehilangan kontrol dirinya. Dalam penelitian ini, yang dimaksud dengan empati dalam perkuliahan adalah suatu kemampuan seseorang untuk mengenali, mempersepsi, serta merasakan perasaan orang lain yang disertai dengan ungkapan dan tindakan, yang tercermin dalam sikap: a) mendengarkan pembicaraan orang lain dengan baik, artinya individu mampu memberi perhatian dan menjadi pendengar yang baik dari segala permasalahan yang diungkapkan orang lain kepadanya, b) menerima sudut pandang orang lain, artinya individu mampu memandang permasalahan dari titik pandang orang lain sehingga akan menimbulkan toleransi dan kemampuan menerima perbedaan, c) peka terhadap perasaan orang lain, artinya individu mampu membaca perasaan orang lain dari isyarat verbal dan non verbal seperti nada bicara, ekspresi wajah, gerak-gerik dan bahasa tubuh lainnya, dan d) tidak larut atau tetap kontrol emosi diri, artinya seseorang dapat mengendalikan diri dalam membantu memecahkan masalah. 
10) Tanggung Jawab

Tanggung jawab adalah berbuat sebagai perwujudan kesadaran akan kewajibannya, kesiagaan seseorang terhadap suatu peristiwa yang ada di sekitarnya mengenai kewajiban atau beban yang harus dipenuhi sebagai akibat dari perbuatan sendiri maupun sebagai akibat perbuatan pihak lain. Dalam penelitian ini, yang dimaksud dengan tanggung jawab dalam perkuliahan adalah sikap dan perilaku untuk melaksanakan tugas dan kewajiban sebagaimana yang seharusnya dilakukan, baik terhadap diri sendiri, teman maupun dosen, yang tercermin dalam sikap: a) melaksanakan tugas individu dengan baik, b) menerima risiko dari tindakan yang dilakukan, c) tidak menyalahkan/menuduh orang lain tanpa bukti yang akurat, d) mengembalikan barang yang dipinjam, e) mengakui dan meminta maaf atas kesalahan yang dilakukan, serta f) melaksanakan apa yang pernah dikatakan tanpa disuruh/diminta.

\section{b. Aspek Pengerjaan Tugas-tugas}

Pengerjaan tugas-tugas

dimaksud dalam penelitian ini berkenaan dengan penyelesaian tugas yang diberikan oleh dosen ke mahasiswa saat proses perkuliahan guna mencapai tujuan pembelajaran yang telah ditentukan sebelumnya, melalui penilaian berbasis kinerja dalam bentuk praktikum, presentasi, diskusi, dan penulisan buah pikiran (makalah).

\section{1) Praktikum}

Praktikum dalam KBBI diartikan sebagai bagian dari pengajaran yang bertujuan agar siswa mendapat kesempatan untuk menguji dan melaksanakan dalam keadaan nyata apa yang diperoleh dalam teori. Praktikum adalah cara penyajian pelajaran kepada siswa untuk melakukan percobaan dengan mengalami dan membuktikan sesuatu yang dipelajari. Dalam penelitian ini yang dimaksud dengan praktikum adalah cara penyajian suatu pelajaran kepada peserta didik, melalui kegiatan mengalami dan membuktikan sendiri apa yang dipelajarinya, dengan memperhatikan unsur-unsur seperti a) persiapan, b) pelaksanaan (urutan langkah kerja dan waktu, serta keselamatan kerja dan kebersihan), c) hasil, dan d) laporan (sistematika paparan dan bahasa, serta kejelasan simpulan).

\section{2) Presentasi}

Presentasi merupakan bagian dari penilaian autentik. Penilaian autentik merupakan penilaian langsung (direct assessment) yang berbasis kinerja. Presentasi merupakan sebuah kegiatan aktif dimana seorang pembicara menyampaikan dan mengkomunikasikan ide serta informasi kepada sekelompok audiens. Dalam penelitian ini, yang dimaksud dengan presentasi adalah suatu kegiatan komunikasi lisan mengenai penyampaian gagasan atau fakta tertentu kepada orang lain dengan berbagai tujuan, dengan menekankan pada unsur: a) penguasaan terhadap materi yang dipresentasikan, b) sistematika presentasi, c) penggunaan bahasa, d) ketepatan intonasi dan kejelasan artikulasi, e) kemampuan memanfaatkan media presentasi, dan f) kemampuan mempertahankan dan menanggapi pertanyaan atau sanggahan.

\section{3) Diskusi}

Diskusi adalah suatu cara penyampaian pelajaran dimana pendidik bersama-sama peserta didik mencari jalan pemecahan atas persoalan yang dihadapi. Diskusi pada dasarnya adalah bertukar informasi, pendapat, dan unsur-unsur pengalaman secara teratur dengan maksud untuk mendapat pengertian bersama yang lebih jelas dan lebih cermat tentang permasalahan atau topik yang sedang dibahas. Dalam penelitian ini yang dimaksud dengan diskusi adalah suatu proses pembelajaran dimana pendidik memberi kesempatan kepada para peserta didik/kelompok untuk mengadakan perbincangan ilmiah guna mengumpulkan pendapat, membuat kesimpulan atau menyusun berbagai alternatif pemecahan atas sesuatu masalah, dengan unsur-unsur penilaian meliputi: a) kemampuan bekerjasama dalam kelompok, b) kemampuan berkomunikasi secara lisan 
(menyampaikan ide/gagasan/komentar), c) kemampuan mengajukan pertanyaan, d) kemampuan menjawab pertanyaan (memberikan penjelasan), dan e) kemampuan menghargai ide, saran, dan pendapat teman.

\section{4) Penulisan buah pikiran (makalah)}

Dalam KBBI, makalah diartikan sebagai karya tulis pelajar atau mahasiswa sebagai laporan hasil pelaksanaan tugas sekolah atau perguruan tinggi. Makalah adalah sebuah uraian tertulis yang membahas tentang suatu permasalahan untuk mendapatkan pembahasan lebih lanjut. Dalam penelitian ini yang dimaksud dengan makalah adalah suatu karya tulis yang mengkaji atau membahas suatu masalah tertentu, ditulis secara runtut dan sistematis, disertai dengan analisis yang logis dan objektif. Beberapa unsur penilaian terkait makalah yang ditekankan dalam penelitian ini meliputi aspek:

1) Umum, menyangkut sistematika makalah dan ketepatan waktu pengumpulan makalah.

2) Isi, menyangkut pendahuluan, pembahasan materi, simpulan, dan penggunaan daftar rujukan atau pustaka.

Dari hasil perhitungan diperoleh nilai validitas isi/konten dari instrumen penilaian proses yang dikembangkan adalah 0.83. Nilai ini kemudian dibandingkan dengan kriteria validitas kontennya, dan diperoleh hasil dalam kategori sangat tinggi.

\section{Berdasarkan}

pedoman pengembangan kurikulum Undiksha 2016 dan buku pedoman studi tahun 2016, penilaian setiap mata kuliah terkait dengan implementasi kurikulum Undiksha 2016 (KKNI) terdiri dari penilaian proses perkuliahan (yang meliputi sikap, partisipasi dalam perkuliahan, penyelesaian tugastugas dengan bobot $60 \%$ ) dan penilaian produk (yang meliputi UTS dan UAS dengan bobot $40 \%$ ). Prodi PTI, sebagai salah satu prodi yang mengimplementasikan kurikulum KKNI, dalam proses penilaiannya belum memiliki instrumen yang standar, terutama yang berkenaan dengan penilaian proses. Akibatnya, masing-masing dosen memiliki asumsi sendiri saat melakukan penilaian proses, sehingga tidak jarang mengabaikan prinsip-prinsip penilaian yakni edukatif, otentik, objektif, akuntabel, dan transparan yang dilakukan secara terintegrasi.

Berkaca dari kondisi tersebut, upaya pembakuan/pengembangan instrumen pun dilakukan. Instrumen yang dikembangkan adalah instrumen penilaian proses, dengan mengacu pada dua (2) aspek, yakni aspek sikap dan partisipasi dalam perkuliahan serta aspek pengerjaan tugas-tugas. Kedua aspek ini dipilih karena menyesuaikan dengan standar penilaian dalam pengimplementasian kurikulum KKNI. Dalam proses pengembangannya, sebelum dihasilkan suatu instrumen yang valid, hal pertama yang dilakukan saat proses pengembangan instrumen adalah melakukan kajian teoritik untuk merumuskan aspek-aspek atau indikator yang hendak dibuat. Dari proses perumusan aspek-aspek atau indikator ini dihasilkan indikator untuk aspek sikap dan partisipasi dalam perkuliahan meliputi kedisiplinan, penampilan, kesantunan, kemampuan bekerjasama, kemampuan berkomunikasi, komitmen, keteladanan, semangat, empati, dan tanggung jawab. Sementara untuk aspek pengerjaan tugastugas dihasilkan rumusan indikator terkait dengan pengerjaan tugas praktikum, presentasi, diskusi, serta penulisan buah pikiran (makalah).

Setelah melakukan kajian teoritik untuk merumuskan aspek-aspek atau indikator yang hendak dibuat, tahap berikutnya dari proses pengembangan instrumen adalah menyusun kisi-kisi instrumen. Berdasarkan kisi-kisi instrumen yang telah disusun ini kemudian dilakukan penyusunan butir-butir instrumen. Selanjutnya, butir-butir instrumen yang telah disusun ini kemudian divalidasi melalui validasi teoritik. Validasi teoritik merupakan tahap validasi melalui pemeriksaan pakar. Jumlah pakar yang dilibatkan saat melakukan validasi teoritik adalah 2 orang, yaitu Nyoman Sugihartini, S.Pd., M.Pd dan I Gede Partha Sindu, S.Pd., M.Pd. Kedua pakar ini, memiliki keahlian dibidang desain pembelajaran dan 
pengembangan instrumen. Saat proses validasi teoritik dilakukan, kedua pakar ini diberi lembar evaluasi yang sama untuk mengevaluasi instrumen, yang didasarkan pada 3 (tiga) aspek, yaitu konten, bahasa, dan sajian atau format. Hasil validasi dari kedua pakar ini kemudian ditabulasi, untuk selanjutnya dilakukan perhitungan besaran nilai koefisien validitas kontennya menggunakan formula Gregory. Dari hasil perhitungan diperoleh nilai validitas isi/konten dari instrumen penilaian proses yang dikembangkan adalah 0.83 . Nilai ini berada dalam kategori sangat tinggi.
Beberapa masukan yang diberikan oleh pakar, terkait dengan instrumen penilaian proses yang dikembangkan yaitu dari pakar 1, bapak I Gede Partha Sindu, S.Pd., M.Pd memberikan masukan supaya tata tulis yang digunakan dalam instrumen disesuaikan dengan KBBI. Sedangkan masukan dari pakar 2, yakni ibu Nyoman Sugihartini, S.Pd., M.Pd, menyarankan agar skala pada penilaian sikap menggunakan skala politomi tidak dikotomi. Berikut hasil validasi dari kedua pakar, sebagaimana yang tersaji dalam Tabel 1.

Tabel 1. Tabulasi Data Hasil Validasi Pakar

\begin{tabular}{|l|l|c|c|}
\hline \multirow{2}{*}{ Pakar } & & \multicolumn{2}{|c|}{ Pakar 1 } \\
& & I Gede Partha Sindu, S.Pd., M.Pd. \\
\cline { 2 - 4 } & Penilaian Pakar & Tidak Relevan & Relevan \\
\hline \multirow{2}{*}{$\begin{array}{l}\text { Pakar 2 } \\
\text { Nyoman Sugihartini, } \\
\text { S.Pd., M.Pd }\end{array}$} & Tidak Relevan & (A) & (B) \\
\cline { 2 - 4 } & Relevan & 0 & 1 \\
\hline
\end{tabular}

\section{SIMPULAN}

Berdasarkan hasil penelitian dan pembahasan yang telah dipaparkan, dapat dibuat beberapa simpulan yakni sebagai berikut, yaitu : Pertama, aspek-aspek atau indikator yang ada dalam penilaian proses yang meliputi aspek sikap dan partisipasi dalam perkuliahan terdiri dari kedisiplinan, penampilan, kesantunan, kemampuan bekerjasama, kemampuan berkomunikasi, komitmen, keteladanan, semangat, empati, dan tanggung jawab. Sementara untuk aspek pengerjaan tugas-tugas terdiri dari praktikum, presentasi, diskusi, serta penulisan buah pikiran (makalah).

Kedua, kisi-kisi dari instrumen penilaian proses dikembangkan berdasarkan 2 (dua) aspek, yaitu aspek sikap dan partisipasi dalam perkuliahan serta aspek pengerjaan tugas-tugas.

Ketiga, rubrik dari instrumen penilaian proses dikembangkan dengan menggunakan skala politomi, baik untuk aspek sikap dan partisipasi dalam perkuliahan maupun aspek pengerjaan tugas-tugas.
Keempat, hasil uji validitas isi oleh dua orang pakar yang dianalisis menggunakan formula Gregory adalah 0.83 . Nilai ini berada dalam kategori sangat tinggi.

\section{REFERENSI}

[1] Widya Wati. Pengembangan Rubrik Asesmen Keterampilan Proses Sains pada Pembelajaran IPA SMP. Jurnal Ilmiah Pendidikan Fisika 'Al-BiRuNi'. 2016. Volume 5, Nomor 1, Maret 2016

[2] Nazwatul Ilmi. Pengembangan Instrumen Penilaian Keterampilan Proses Sains pada Pembelajaran Fisika SMA. Prosiding Seminar Nasional Fisika. 2016. (E-Journal) VOLUME V, OKTOBER 2016

[3] Juhji.. Peningkatan Keterampilan Proses Sains Siswa Melalui Pendekatan Inkuiri Terbimbing. Jurnal Penelitian dan Pembelajaran IPA. 2016). Vol. 2, No. 1, Juni 2016 
[4] Asep Jihad.. Evaluasi Pembelajaran. Yogyakarta: Multi Pressindo. 2008.

[5] Hamzah B. Uno. Asessment Pembelajaran. Jakarta: Bumi Aksara. 2012.

[6] Koyan, I Wayan. Asesmen dalam Pembelajaran. Singaraja: Universitas Pendidikan Ganesha Press. 2011.

[7] Candiasa, I Made. Pengujian Instrumen Penelitian Disertai Aplikasi ITEMAN dan BIGSTEPS. Singaraja: Unit Penerbitan Universitas Pendidikan Ganesha. 2010. 